Archive for

Organic Chemistry

Arkivoc 2020, part iv, 25-34

\title{
Convenient access to stable $\beta$-fluorovinyl-substituted 1,2-benziodoxolones
}

\section{Tsugio Kitamura, ${ }^{\text {a }}{ }^{\text {Rinka Sato, }}{ }^{\text {a }}$ Hikari Morita, ${ }^{a}$ Daichi Kitamura, ${ }^{a}$ Juzo Oyamada, ${ }^{a}$ Masahiro Higashi, ${ }^{b}$ and Yosuke Kishikawab}

${ }^{a}$ Department of Chemistry and Applied Chemistry, Saga University, Honjo-machi, Saga 840-8502, Japan;

${ }^{2}$ Daikin Industries, Ltd., Settsu, Osaka 566-8585, Japan

Email: kitamura@cc.saga-u.ac.jp

Received 07-10-2020

Accepted 08-26-2020

Published on line 09-06-2020

\section{Abstract}

A convenient synthesis of 1-(2-fluorovinyl)-1,2-benziodoxol-3(1H)-ones was described. Fluorination reaction of alkynes with the reagent from $o$-iodobenzoic acid, mCPBA and HF.py was conducted in DCM and followed by addition of $\mathrm{BF}_{3} \cdot \mathrm{OEt}_{2}$ at $-65{ }^{\circ} \mathrm{C}$. Treatment of the reaction mixture with $\mathrm{NaHCO}_{3}$ gave 1-(2fluorovinyl)benziodoxolones as stable solids. The similar fluorination reaction of alkynes using 1-hydroxy-1,2benziodoxol-3(1H)-one and HF.py also gave the same products.

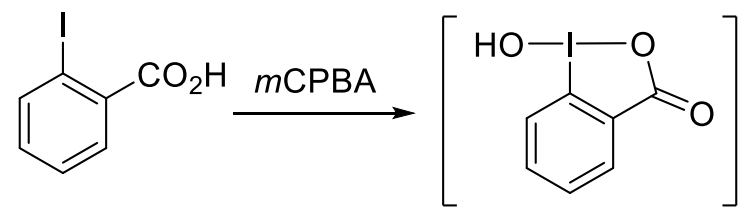

1. HF.py, alkyne

2. $\mathrm{BF}_{3} \cdot \mathrm{OEt}_{2},-65{ }^{\circ} \mathrm{C}$ to $\mathrm{rt}$

3. $\mathrm{NaHCO}_{3}$

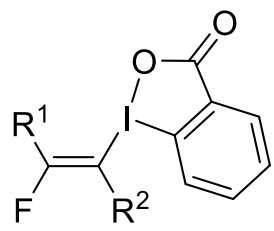

Keywords: Fluorination; hypervalent iodine; hydrogen fluoride; alkyne; 1 -( $\beta$-fluorovinyl)-1,2-benziodoxol$3(1 H)$-one 


\section{Introduction}

Substance $P(S P)$ is an undecapeptide member of the tachykinin neuropeptide family, containing a chain of eleven amino acid residues, and it acts as a neurotransmitter and as a neuromodulator. ${ }^{1}$ However, major problem is rapid degradation by peptidases in the use of peptides as therapeutic agents. To overcome the drawback, non-hydrolysable amide isosteres are used as an established approach. In 1990, Allmendinger and his coworkers reported that a fluoroalkene unit is an excellent amide bond substitute mimicking both steric and electronic features of the peptide bond..$^{2-4}$ Fluoroalkenes have a similarity in chemical and structural properties to amide groups and are stable enough against hydrolysis. When the amide bond of SP between Phe (phenylalanine)-Gly (glycine) is replaced by an isosteric fluorovinyl unit, the isosteres cannot be cleaved by peptidases, causing a significant biological activity. Particularly, in receptor binding assays, the fluoroalkene isostere is nearly as active as SP itself. ${ }^{2,3}$

Recently hypervalent iodine compounds have received much attention due to their synthetically useful nature such as mild oxidation property, chemical behavior similar to transition metals, and excellent leaving ability. ${ }^{5-9}$ As the building block for fluoroalkene synthesis, as shown in Scheme 1 , a $\beta$-fluorovinyliodonium salt is an excellent candidate because phenyliodonio group $\left(\mathrm{Phl}^{+}\right)$is readily replaceable with many functional groups under mild conditions due to its superleaving ability, which is nearly $10^{6}$ times more reactive than triflate group. $^{10}$ Therefore, the synthetic conditions of fluoroalkenes become milder than those of conventional methods.

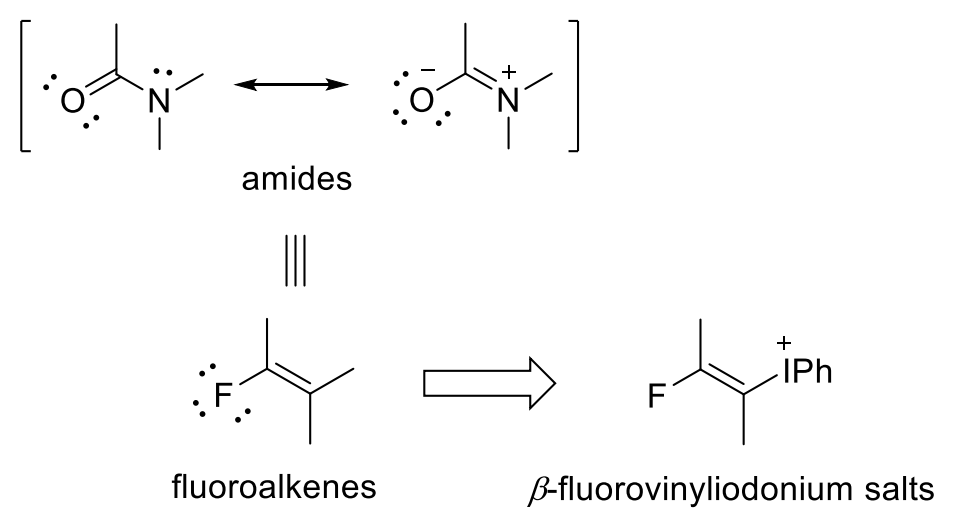

Scheme 1. Fluorovinyliodonium salts as the building block of fluoroalkenes.

There are some applications as the building block. Hara and his coworkers demonstrated the utility of $\beta$-fluorovinyliodonium salts as the building block for fluorine-containing compounds, ${ }^{11-16}$ where the utility has been shown by several coupling reactions such as carbomethoxylation, Heck coupling, Stille coupling, Sonogashira coupling, and Suzuki coupling.

Scheme 2 shows the synthetic methods of $\beta$-fluorovinyliodonium salts reported previously, including (a) the reaction of terminal alkynes with $p$-(difluoroiodo)toluene in the presence of $\mathrm{HF}_{\text {or }} \mathrm{HBF}_{4}{ }^{16,18}$ (b) the reaction of alkynyliodonium salts with aqueous hydrofluoric acid, ${ }^{15,17}$ and (c) the reaction of alkynes with PhIO/HF reagent. ${ }^{19}$ 


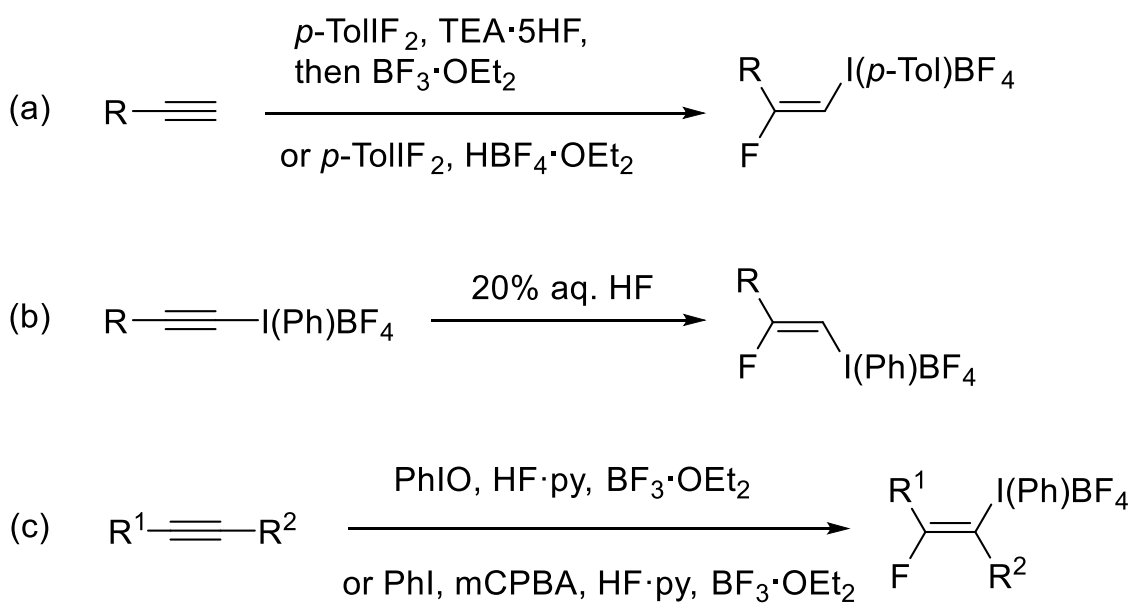

Scheme 2. Previous works on synthesis of $\beta$-fluorovinyliodonium salts.

Although $\beta$-fluorovinyliodonium salts are stable enough to handle, they lack stability enough to be stored for long periods under atmospheric conditions. Also, some iodonium salts have poor crystallinity and are oils, so handling is troublesome. Therefore, we envisioned incorporation of a rigid structure into the $\beta$ fluorovinyliodonium salts to increase their crystallinity and stability (Scheme 3). Benziodoxolones bearing a 5menbered ring fit this purpose because they show a high thermal stability due to the bridging of the equatorial and apical positions by the 5-membered ring and the overlap of the lone pair electrons with the p-orbitals of the benzene ring. ${ }^{8,20}$
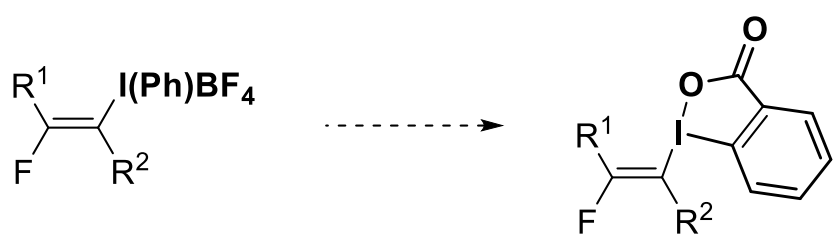

Scheme 3. Introduction of a stable cyclic structure into $\beta$-fluorovinyliodonium salts.

Since we previously developed a convenient synthesis of $\beta$-fluorovinyliodonium salts using the in-situ preparation of iodosylbenzene from iodobenzene, ${ }^{19}$ we applied this procedure to the synthesis of $\beta$ fluorovinyliodonium salts bearing the benzoiodoxolone structure. Thus, we thought to be able to prepare $\beta$ fluorovinylbenziodoxolones from o-iodobenzoic acid.

\section{Results and Discussion}

The synthesis of $\beta$-fluorovinylbenziodoxolones from 0 -iodobenzoic acid was examined using 1 -octyne as a model substrate according to the similar procedure reported before. ${ }^{19}$ o-lodobenzoic acid was treated with mCPBA and then reacted with HF.pyridine complex and 1-octyne (1a). The reaction mixture was treated with $\mathrm{BF}_{3} \cdot \mathrm{OEt}_{2}$ complex, and finally quenched with sodium hydrogen carbonate. The molar ratios of $\mathrm{BF}_{3} \cdot \mathrm{OEt}_{2}$ and $1 \mathrm{a}$ were examined to optimize the conditions. The results are given in Table 1 . The best result (Table 1, entry 2) was obtained using o-iodobenzoic acid $(0.75 \mathrm{mmol}), 1 \mathrm{la}(0.5 \mathrm{mmol}), \mathrm{HF} \cdot \mathrm{py}(10 \mathrm{mmol} \mathrm{HF})$, and $\mathrm{BF}_{3} \cdot \mathrm{OEt}_{2}(5$ $\mathrm{mmol}$ ), giving 2-fluoro-1-octenylbenziodoxolone $2 \mathrm{a}$ in $84 \%$ yield. 
Table 1. Optimization of Fluorination of $1 a^{a}$

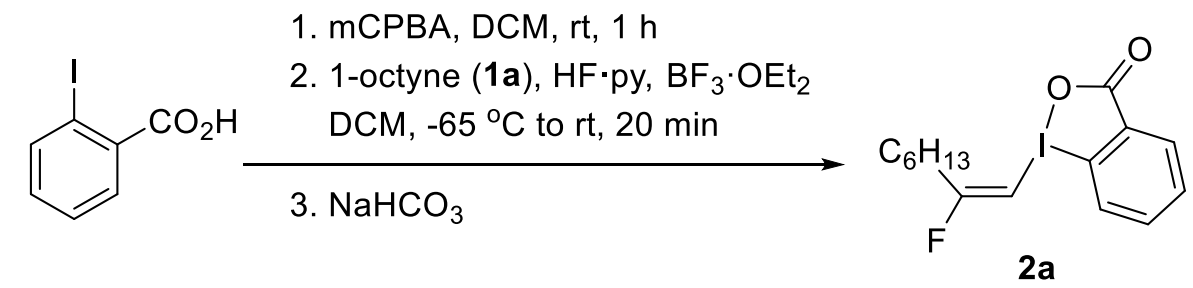

\begin{tabular}{llll}
\hline Entry & $\mathrm{BF}_{3} \cdot \mathrm{OEt}_{2}(\mathrm{mmol})$ & $\mathbf{1 a}(\mathrm{mmol})$ & Yield $_{(\%)^{b}}$ \\
\hline 1 & 2 & 0.5 & 42 \\
2 & 5 & 0.5 & 84 \\
3 & 10 & 0.5 & 78 \\
4 & 5 & 0.75 & 66 \\
\hline
\end{tabular}

${ }^{a}$ Conditions: $o$-iodobenzoic acid $(0.75 \mathrm{mmol}), \mathrm{DCM}(1 \mathrm{~mL}), 1 \mathrm{~h}$; 1-octyne (1a), HF.py (10 mmol HF), DCM (1 mL); $\mathrm{BF}_{3} \cdot \mathrm{OEt}_{2},-65^{\circ} \mathrm{C}$ to rt, $20 \mathrm{~min} .{ }^{b}$ Yields are determined by ${ }^{19} \mathrm{~F} \mathrm{NMR}$.

The stereochemistry of 2-fluoro-1-octenylbenziodoxolone $2 \mathrm{a}$ was determined by ${ }^{1} \mathrm{H}$ NMR. The vinylic proton appeared at $6.59 \mathrm{ppm}$ and coupled with fluorine atom. The coupling constant ${ }^{3} \mathrm{~J}_{\mathrm{H}-\mathrm{F}}$ was $18 \mathrm{~Hz}$. This value was in good agreement with the $(E)$ geometry of $(E)$-2-fluoro-1-octenyl(phenyl)iodonium tetrafluoroborate, ${ }^{3} \mathrm{~J}_{\mathrm{H}-\mathrm{F}}=15 \mathrm{~Hz} .{ }^{19}$ There is an obvious difference in melting point between non-cyclic 2-fluoro1-octenyl(phenyl)iodonium tetrafluoroborate and benziodoxolone $2 \mathrm{a}, 52-53{ }^{\circ} \mathrm{C}^{19}$ and $118-119{ }^{\circ} \mathrm{C}$. The melting point of the benziodoxolone $\mathbf{2 a}$ is much higher. In addition, to evaluate the thermal stability, the mass change of the samples was measured by TG. The temperatures at which $1 \%$ weight loss occurred were compared under a nitrogen atmosphere. As shown in Table 2, the $1 \%$ weight loss temperature of 2 a was $194.6{ }^{\circ} \mathrm{C}$, and that of 2-fluoro-1-octenyl(phenyl)iodonium tetrafluoroborate was $135.6^{\circ} \mathrm{C}$. Clearly, $2 \mathrm{a}$ was found to be more thermally stable than 2-fluoro-1-octenyl(phenyl)iodonium tetrafluoroborate.

Table 2. Thermal stability of $\beta$-fluorovinyliodonium salts

\begin{tabular}{llll}
\hline Entry & lodonium salts & $\mathrm{Mp}\left({ }^{\circ} \mathrm{C}\right)$ & $1 \%$ Weight loss temperature $\left({ }^{\circ} \mathrm{C}\right)$ \\
\hline 1 & $2 \mathrm{a}$ & $118-119$ & 194.6 \\
2 & $\mathrm{C}_{6} \mathrm{H}_{13}$ & $52-53$ & 135.6 \\
& & & \\
\hline
\end{tabular}

The fluorination reaction of other alkynes 1 with 0 -iodobenzoic acid was conducted. The results are given in Table 3. Terminal alkynes worked well to give good yields of the products $\mathbf{2}$ but the reaction for the internal alkynes resulted in lower yields. This may be attributed to the steric hindrance of the benziodoxolone structure. 
Table 3. Fluorination of Alkynes $\mathbf{1}^{\text {a }}$

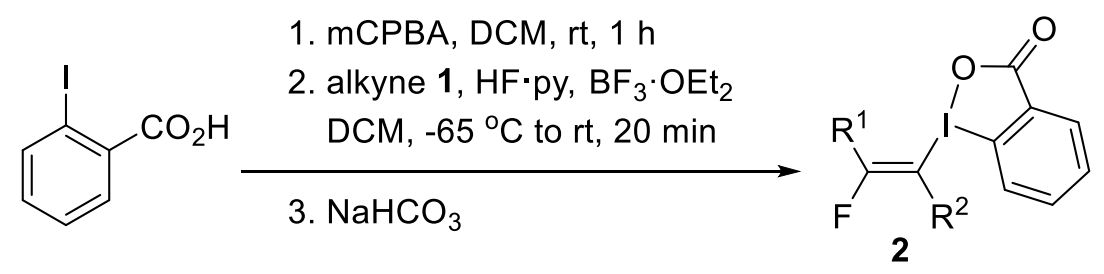

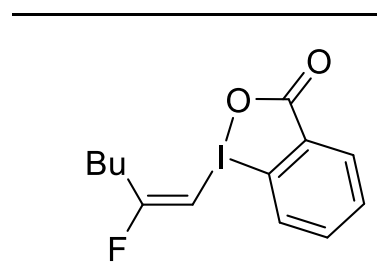

2b: $76 \%$

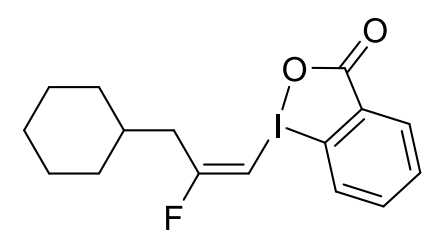

2e: $87 \%$

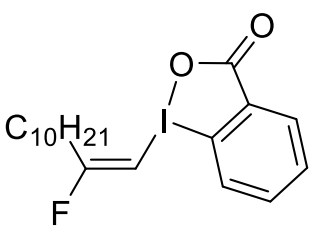

2c: $73 \%$<smiles>CC/C(F)=C(\CC)I1OC(=O)c2ccccc21</smiles>

2f: $18 \%$<smiles>CC(C)CC/C(F)=C\I1OC(=O)c2ccccc21</smiles>

2d: $62 \%$<smiles></smiles>

2g: $27 \%$

a Conditions: o-iodobenzoic acid $(0.75 \mathrm{mmol}), \mathrm{DCM}(1 \mathrm{~mL}), 1 \mathrm{~h} ; 1$ (0.5

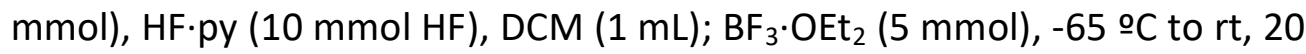
min. Isolated yields are given.

The reaction of alkynes 1 with $\mathrm{HF}$ in the presence of $o$-iodobenzoic acid and mCPBA is considered to proceed as reported previously in the fluorination with reagents combined of hypervalent iodine and $\mathrm{HF}$ (Scheme 4). ${ }^{21-28}$ First, 0 -iodobenzoic acid is oxidized by mCPBA to form 1-hydroxy-1,2-benziodoxolone and then reacts with HF to generate 1-fluoro-1,2-benziodoxolone, which is activated by tetrafluoroboric acid formed from $\mathrm{HF}$ and $\mathrm{BF}_{3}{ }^{16}$ The activated fluorobenziodoxolone reacts with an alkyne 1 to give a $\beta$ fluorovinyliodonium salts. Treatment with sodium hydrogen carbonate affords a cyclized $\beta$ fluorovinylbenziodoxolone $\mathbf{2}$. 

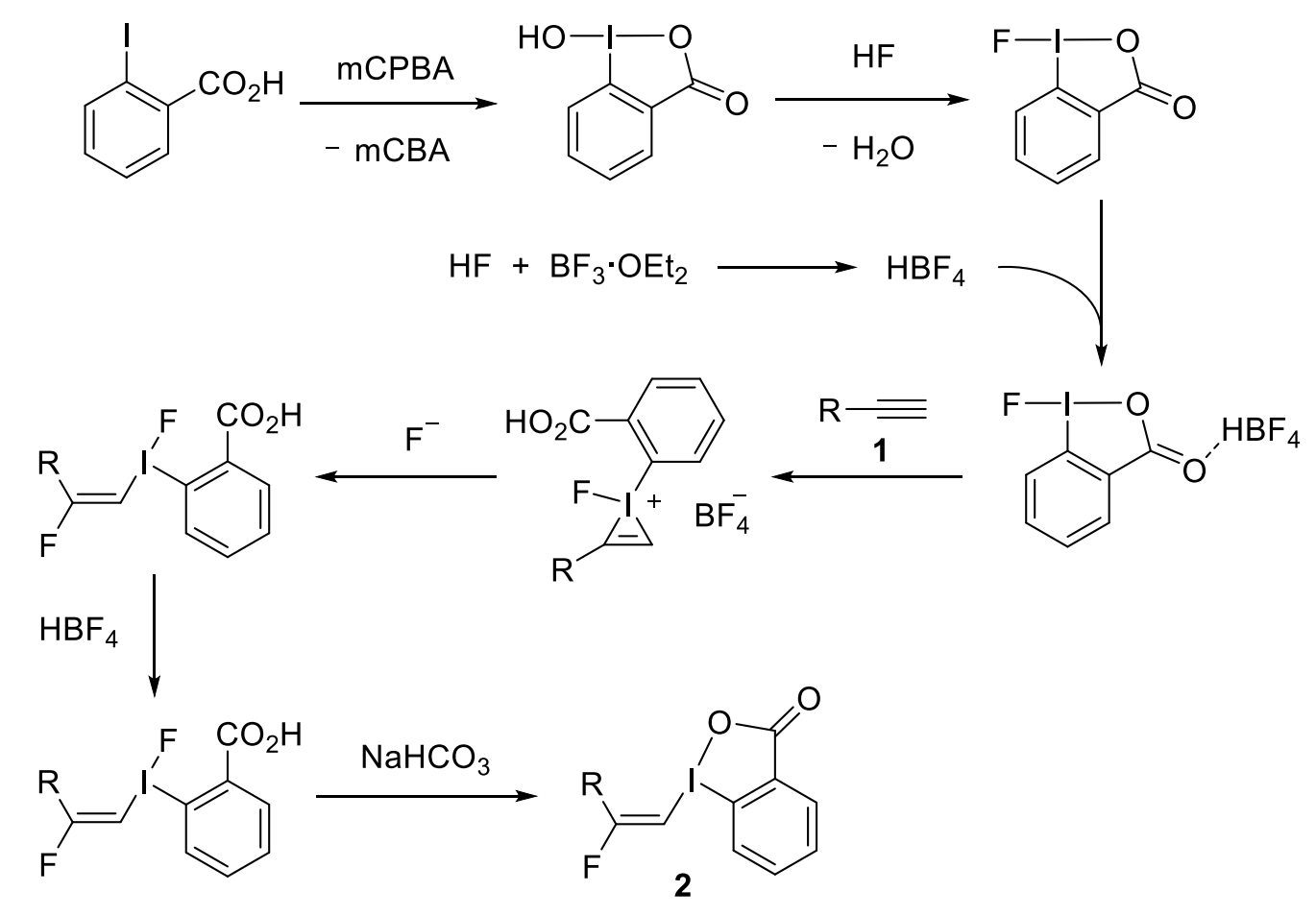

Scheme 4. A possible mechanism.

In the synthesis of $\beta$-fluorovinylbenziodoxolone 2, 1-hydroxybenziodoxolone is expected to be a key intermediate which is formed in situ by oxidation of o-iodobenzoic acid with mCPBA. Thus, we re-examined the fluorination of alkynes 1 using 1-hydroxybenziodoxolone. Synthesis of 1-hydroxybenziodoxolone was conducted according to the literature methods. ${ }^{29,30}$ The reaction of alkynes 1 in the presence of HF.py was conducted using 1.5 equiv of 1-hydroxybenziodoxolone. Treatment of 1 with 1-hydroxybenziodoxolone in the presence of HF.py followed by addition of $\mathrm{BF}_{3} \cdot \mathrm{OEt}_{2}$ gave the desired 2-fluoroalkenylbenziodoxolones 2 after treatment with aqueous $\mathrm{NaHCO}_{3}$. The results are given in Table 4. 
Table 4. Fluorination of 1 Using 1-Hydroxy-1,2-benziodoxolone ${ }^{a}$

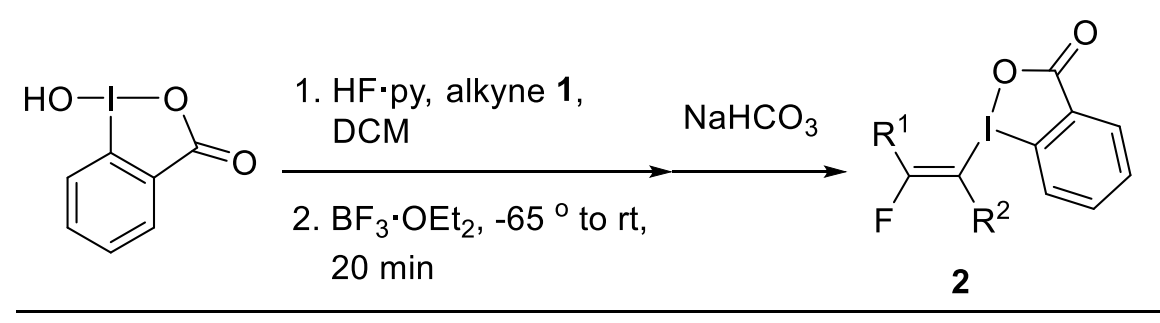

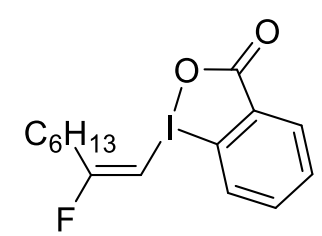

2a: $79 \%$<smiles>CC(C)(C)C=CI1OC(=O)c2ccccc21</smiles>

2b: $73 \%$

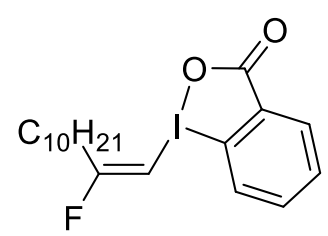

2c: $69 \%$<smiles>CC/C(F)=C(\CC)I1OC(=O)c2ccccc21</smiles>

2f: $53 \%$<smiles></smiles>

2g: $24 \%$

a Conditions: 1-hydroxy-1,2-benziodoxolone (0.3 mmol), HF.py (4 $\mathrm{mmol} \mathrm{HF})$, alkyne 1 (0.2 mmol), DCM (0.5 mL); BF $3 . \mathrm{OEt}_{2}(2 \mathrm{mmol})$, $65 \stackrel{\circ}{\circ}$ to rt, $20 \mathrm{~min}$. Isolated yields are given.

The similar results were obtained in the case of the reaction with 1-hydroxy-1,2-benziodoxolone. The fluorination of terminal alkynes 1a-1c gave the desired products $\mathbf{2}$ in good yields, while that of internal alkynes 1f and $\mathbf{1 g}$ resulted in moderate yields of the products 2 . These results clearly indicate that 1-hydroxy-1,2benziodoxolone is a key intermediate.

\section{Conclusions}

In conclusion, we have developed convenient methods for synthesis of stable 1-(2-fluorovinyl)-1,2benziodoxolones. The fluorination reaction is achieved in the presence of HF.py using o-iodobenzoic acid in the presence of mCPBA or 1-hydroxy-1,2-benziodoxolone. Compared with non-cyclic 2-fluorovinyliodonium salts, 1-(2-fluorovinyl)-1,2-benziodoxolones 2 indicate a considerable advantage in the ease of handling and the stability for storage. In addition to good yields of the products, the convenient procedure facilitates the approach to synthesis of valuable fluoroalkanes as the building block.

\section{Experimental Section}

General. All solvents and starting materials were used as received without further purification unless otherwise indicated. ${ }^{1} \mathrm{H}$ NMR $(400 \mathrm{MHz}),{ }^{13} \mathrm{C}$ NMR $(100 \mathrm{MHz})$, and ${ }^{19} \mathrm{~F} \mathrm{NMR}(376 \mathrm{MHz})$ spectra were recorded on an Agilent 400-MR NMR spectrometer. High-resolution mass spectra were measured by the Analytical 
Center, Institute for Materials Chemistry, Kyushu University. TG was analyzed by Technology and Inovation Center, Daikin Industries. Melting points were measured with a YANACO micro melting apparatus and are uncorrected. Column chromatographic separation was carried out using Silica Gel 60. Pre-coated plates (silica gel $60 \mathrm{~F}_{254}$, MERCK) were used for TLC examination.

1-(2-Fluorovinyl)-1,2-benziodoxol-3(1H)-ones 2 using o-iodobenzoic acid/mCPBA. To a Teflon tube were placed o-iodobenzoic acid (186 mg, $0.75 \mathrm{mmol}$ ), mCPBA (65\%, $199 \mathrm{mg}, 0.75 \mathrm{mmol})$, and DCM (1 mL). The mixture was stirred at room temperature for $1 \mathrm{~h}$, and then HF.py $(0.26 \mathrm{~mL}, 10 \mathrm{mmol} \mathrm{HF})$, alkyne 1 (0.5 mmol), $\mathrm{DCM}(1 \mathrm{~mL})$ were added at this temperature. After cooling to $-65^{\circ} \mathrm{C}, \mathrm{BF}_{3} \cdot \mathrm{Et}_{2} \mathrm{O}(0.62 \mathrm{~mL}, 5.0 \mathrm{mmol})$ was added and stirred for $10 \mathrm{~min}$. The reaction mixture was stirred at room temperature for $20 \mathrm{~min}$. The reaction mixture was poured into water $(10 \mathrm{~mL})$ containing $\mathrm{NaHCO}_{3}(1.26 \mathrm{~g}, 15 \mathrm{mmol})$ and extracted with $\mathrm{DCM}(10 \mathrm{~mL} \times 3)$. The combined organic layer was dried over anhydrous $\mathrm{Na}_{2} \mathrm{SO}_{4}$. Evaporation of the solvent gave crude viscous crystalline products 2, which was submitted to column chromatography on silica gel. Elution with $5 \%$ $\mathrm{MeOH} /$ EtOAc gave pure crystalline products.

1-(2-Fluorovinyl)-1,2-benziodoxol-3(1H)-ones 2 using 1-hydroxy-1,2-benziodoxol-3(1H)-one. To a Teflon tube were placed 1-hydroxy-1,2-benziodoxol-3(1H)-one (73.8 mg, $0.3 \mathrm{mmol})$, HF.py (0.1 mL, $4 \mathrm{mmol} \mathrm{HF})$, alkyne 1 $(0.2 \mathrm{mmol}), \mathrm{DCM}(0.5 \mathrm{~mL})$ were added and stirred at room temperature for $10 \mathrm{~min}$. After cooling to $-65^{\circ} \mathrm{C}$, $\mathrm{BF}_{3} \cdot \mathrm{Et}_{2} \mathrm{O}(0.25 \mathrm{~mL}, 2.0 \mathrm{mmol})$ was added and stirred for $10 \mathrm{~min}$. The reaction mixture was stirred at room temperature for $20 \mathrm{~min}$. The reaction mixture was poured into water $(10 \mathrm{~mL})$ containing $\mathrm{NaHCO}_{3}(0.5 \mathrm{~g}, 6$ mmol) and extracted with DCM $(10 \mathrm{~mL} \times 3)$. The combined organic layer was dried over anhydrous $\mathrm{Na}_{2} \mathrm{SO}_{4}$. Evaporation of the solvent gave crude viscous crystalline products 2, which was submitted to column chromatography on silica gel. Elution with $5 \% \mathrm{MeOH} /$ EtOAc gave pure crystalline products.

1-[(E)-2-Fluoro-1-octen-1-yl]-1,2-benziodoxol-3(1H)-one (2a). The product was obtained as white solids, mp 118-119 ${ }^{\circ} \mathrm{C} .{ }^{1} \mathrm{H}$ NMR $\left(400 \mathrm{MHz}, \mathrm{CD}_{3} \mathrm{OD}\right): \delta 0.80(\mathrm{t}, J 7 \mathrm{~Hz}, 3 \mathrm{H}), 1.17-1.35(\mathrm{~m}, 6 \mathrm{H}), 1.57-1.64(\mathrm{~m}, 2 \mathrm{H}), 2.75(\mathrm{dt}, J \mathrm{~J}$, $23 \mathrm{~Hz}, 2 \mathrm{H}), 6.59(\mathrm{~d}, J 18 \mathrm{~Hz}, 1 \mathrm{H}), 7.71-7.76(\mathrm{~m}, 3 \mathrm{H}), 8.27(\mathrm{~d}, J 7 \mathrm{~Hz}, 2 \mathrm{H}) .{ }^{13} \mathrm{C}\left\{{ }^{1} \mathrm{H}\right\} \mathrm{NMR}\left(100 \mathrm{MHz}, \mathrm{DMSO}-d_{6}\right)$ : $\delta$ 5.0, 14.1, 17.8, 20.2, 23.1, 23.2 (d, J 26 Hz), 72.6 (d, J 29 Hz), 105.9, 119.2, 122.7, 124.0, 124.8, 126.2, 160.7, 166.9 (d, J $283 \mathrm{~Hz}$ ). ${ }^{19} \mathrm{~F} \mathrm{NMR} \mathrm{(376} \mathrm{MHz,} \mathrm{CD} \mathrm{CD}_{3}$ ): $\delta$-68.2. HRMS (FAB, double focusing): $\mathrm{m} / \mathrm{z}[\mathrm{MH}]^{+}$calcd for $\mathrm{C}_{15} \mathrm{H}_{19} \mathrm{FlO}_{2}$ : 377.0408; found: 377.0414 .

1-[(E)-2-Fluoro-1-hexen-1-yl]-1,2-benziodoxol-3(1H)-one (2b). The product was obtained as white solids; $\mathrm{mp}$ $138{ }^{\circ} \mathrm{C} .{ }^{1} \mathrm{H}$ NMR $\left(400 \mathrm{MHz}, \mathrm{CD}_{3} \mathrm{OD}\right): \delta 0.87(\mathrm{t}, J 7 \mathrm{~Hz}, 3 \mathrm{H}), 1.31-1.40(\mathrm{~m}, 2 \mathrm{H}), 1.56-1.63(\mathrm{~m}, 2 \mathrm{H}), 2.75(\mathrm{dt}, J 7,22$ $\mathrm{Hz}, 2 \mathrm{H}), 6.58(\mathrm{~d}, J 19 \mathrm{~Hz}, 1 \mathrm{H}), 7.70-7.78(\mathrm{~m}, 3 \mathrm{H}), 8.27(\mathrm{~d}, J 7 \mathrm{~Hz}, 1 \mathrm{H}) .{ }^{13} \mathrm{C}\left\{{ }^{1} \mathrm{H}\right\} \mathrm{NMR}\left(100 \mathrm{MHz}, \mathrm{CD}_{3} \mathrm{OD}\right): \delta=14.3$, 23.3, 29.6, 32.6 (d, J $26 \mathrm{~Hz}$ ), 82.1 (d, J $28 \mathrm{~Hz}$ ), 115.5, 132.8, 132.3, 133.6, 134.4, 135.8, 170.3, 176.5 (d, J 283 $\mathrm{Hz}$ ). ${ }^{19} \mathrm{~F}$ NMR (376 MHz, CD $\mathrm{OD}$ ): $\delta=-63.3$. HRMS (FAB, double focusing): $\mathrm{m} / z[\mathrm{MH}]^{+}$calcd for $\mathrm{C}_{13} \mathrm{H}_{15} \mathrm{FIO}_{2}$ : 349.0095; found: 349.0101.

1-[(E)-2-Fluoro-1-dodecen-1-yl]-1,2-benziodoxol-3(1H)-one (2c). The product was obtained as white solids, $\mathrm{mp} 98^{\circ} \mathrm{C} .{ }^{1} \mathrm{H}$ NMR $\left(400 \mathrm{MHz}, \mathrm{CD}_{3} \mathrm{OD}\right): \delta 0.87(\mathrm{t}, J 7 \mathrm{~Hz}, 3 \mathrm{H}), 1.20-1.30(\mathrm{~m}, 14 \mathrm{H}), 1.57-1.64(\mathrm{~m}, 2 \mathrm{H}), 2.68(\mathrm{dt}, J \mathrm{~J}$, $22 \mathrm{~Hz}, 2 \mathrm{H}), 6.17(\mathrm{~d}, J 19 \mathrm{~Hz}, 1 \mathrm{H}), 7.54(\mathrm{~d}, J 8 \mathrm{~Hz}, 1 \mathrm{H}), 7.64-7.71(\mathrm{~m}, 2 \mathrm{H}), 8.46(\mathrm{dd}, J 2,7 \mathrm{~Hz}, 1 \mathrm{H}) .{ }^{13} \mathrm{C}\left\{{ }^{1} \mathrm{H}\right\} \mathrm{NMR}$ $\left(100 \mathrm{MHz} \mathrm{CDCl}_{3}\right): \delta=14.8,24.0,27.4,30.1,30.5,30.7,30.8,30.9,32.7$ (d, J $\left.26 \mathrm{~Hz}\right), 33.3,82.3$ (d, J $\left.28 \mathrm{~Hz}\right)$, 115.6, 128.8, 132.3, 133.6, 134.4, 135.7, 170.2, 176.4 (d, J $283 \mathrm{~Hz}) .{ }^{19} \mathrm{~F} \mathrm{NMR}\left(376 \mathrm{MHz}, \mathrm{CDCl}_{3}\right): \delta=-62.7$. HRMS (FAB, double focusing): $m / z[\mathrm{MH}]^{+}$calcd for $\mathrm{C}_{19} \mathrm{H}_{27} \mathrm{FIO}_{2}: 433.1034$; found: 433.1040 .

1-[(E)-2-Fluoro-5-methyl-1-hexen-1-yl]-1,2-benziodoxol-3(1H)-one (2d). The product was obtained as white solids, mp $148{ }^{\circ} \mathrm{C} .{ }^{1} \mathrm{H}$ NMR (400 MHz, DMSO-d 6 ): $\delta 0.79(\mathrm{~d}, J 7 \mathrm{~Hz}, 6 \mathrm{H}), 1.41(\mathrm{q}, J 7 \mathrm{~Hz}, 2 \mathrm{H}), 1.48-1.57(\mathrm{~m}, 1 \mathrm{H})$, $2.67(\mathrm{dt}, J \mathrm{~J}, 23 \mathrm{~Hz}, 2 \mathrm{H}), 6.72(\mathrm{~d}, J 20 \mathrm{~Hz}, 1 \mathrm{H}), 7.63-7.76(\mathrm{~m}, 3 \mathrm{H}), 8.12(\mathrm{dd}, J 2,7 \mathrm{~Hz}, 1 \mathrm{H}) .{ }^{13} \mathrm{C}\left\{{ }^{1} \mathrm{H}\right\} \mathrm{NMR}(100 \mathrm{MHz}$, DMSO- $\left.d_{6}\right): \delta=22.2,27.0,29.3(\mathrm{~d}, J 26 \mathrm{~Hz}), 34.7,83.8$ (d, J $\left.24 \mathrm{~Hz}\right), 114.8,127.3,130.6,131.6,133.8,134.2$, 
165.9, 172.7 (d, J $279 \mathrm{~Hz}$ ). $\left.{ }^{19} \mathrm{~F} \mathrm{NMR} \mathrm{(376} \mathrm{MHz,} \mathrm{DMSO-} d_{6}\right): \delta=-68.0$. HRMS (FAB, double focusing): $\mathrm{m} / z$ [MH] $]^{+}$ calcd for $\mathrm{C}_{14} \mathrm{H}_{17} \mathrm{FIO}_{2}$ : 363.0252; found: 363.0258 .

1-[(E)-3-Cyclohexyl-2-fluoro-1-propen-1-yl]-1,2-benziodoxol-3(1H)-one (2e). The product was obtained as white solids, mp $139{ }^{\circ} \mathrm{C} .{ }^{1} \mathrm{H}$ NMR $\left(400 \mathrm{MHz}, \mathrm{DMSO}-d_{6}\right): \delta 0.88-1.19(\mathrm{~m}, 5 \mathrm{H}), 1.52-1.67(\mathrm{~m}, 6 \mathrm{H}), 2.58(\mathrm{dd}, J 7,24$ $\mathrm{Hz}, 2 \mathrm{H}), 6.77(\mathrm{~d}, J 20 \mathrm{~Hz}, 1 \mathrm{H}), 7.63-7.75(\mathrm{~m}, 3 \mathrm{H}), 8.12(\mathrm{dd}, J 1,7 \mathrm{~Hz}, 1 \mathrm{H}) .{ }^{13} \mathrm{C}\left\{{ }^{1} \mathrm{H}\right\} \mathrm{NMR}\left(100 \mathrm{MHz}, \mathrm{DMSO}-d_{6}\right): \delta=$ 25.6, 25.7, 32.1, 35.3, 38.4 (d, J 25 Hz), 85.0 (d, J 24 Hz), 114.8, 127.4, 130.6, 131.6, 133.7, 134.2, 165.9, 171.6 (d, J $279 \mathrm{~Hz}$ ). ${ }^{19} \mathrm{~F}$ NMR (376 MHz, DMSO- $d_{6}$ ): $\delta=$-65.4. HRMS (FAB, double focusing): $\mathrm{m} / z$ [MH] ${ }^{+}$calcd for $\mathrm{C}_{16} \mathrm{H}_{19} \mathrm{FIO}_{2}$ : 389.0408; found: 389.0412 .

1-[(E)-4-Fluoro-3-hexen-3-yl]-1,2-benziodoxol-3(1H)-one (2f). The product was obtained as white solids; $\mathrm{mp}$ $208{ }^{\circ} \mathrm{C} .{ }^{1} \mathrm{H}$ NMR $\left(400 \mathrm{MHz}, \mathrm{CD}_{3} \mathrm{OD}\right): \delta 1.14(\mathrm{t}, J 7 \mathrm{~Hz}, 3 \mathrm{H}), 1.16(\mathrm{t}, J 7 \mathrm{~Hz}, 3 \mathrm{H}), 2.74(\mathrm{q}, J 7 \mathrm{~Hz}, 2 \mathrm{H}), 2.80(\mathrm{q}, J 7 \mathrm{~Hz}$, $2 \mathrm{H}), 7.69-7.74(\mathrm{~m}, 3 \mathrm{H}), 8.29(\mathrm{~d}, J 8 \mathrm{~Hz}, 1 \mathrm{H}) .{ }^{13} \mathrm{C}\left\{{ }^{1} \mathrm{H}\right\} \mathrm{NMR}\left(100 \mathrm{MHz}, \mathrm{CD}_{3} \mathrm{OD}\right): \delta=11.6,14.4,26.7(\mathrm{~d}, J 7 \mathrm{~Hz}), 28.3$ (d, J $28 \mathrm{~Hz}$ ), 105.3 (d, J $23 \mathrm{~Hz}), 114.2,128.8,132.3,133.9,135.0,135.9,170.0,171.2$ (d, J $279 \mathrm{~Hz}) .{ }^{19} \mathrm{~F} \mathrm{NMR}(376$ $\mathrm{MHz}, \mathrm{CD}_{3} \mathrm{OD}$ ): $\delta=$-79.9. HRMS (FAB, double focusing): $\mathrm{m} / z[\mathrm{MH}]^{+}$calcd for $\mathrm{C}_{13} \mathrm{H}_{15} \mathrm{FIO}_{2}$ : 349.0095; found: 349.0101.

1-[(E)-7-Fluoro-6-dodecen-6-yl]-1,2-benziodoxol-3(1H)-one $\mathbf{( 2 g})$. The product was obtained as white solids; $\mathrm{mp} 106-107{ }^{\circ} \mathrm{C}$; yield. ${ }^{1} \mathrm{H}$ NMR $\left(400 \mathrm{MHz}, \mathrm{CD}_{3} \mathrm{OD}\right): \delta$ 0.70-0.85 (m, 6H), 1.05-1.23 (m, 4H), 1.43-1.50 (m, 4H), 2.61-2.67 (m, 4H), 7.57-7.66 (m, 3H), $8.19(\mathrm{~d}, J 6 \mathrm{~Hz}, 1 \mathrm{H}) .{ }^{13} \mathrm{C}\left\{{ }^{1} \mathrm{H}\right\} \mathrm{NMR}\left(100 \mathrm{MHz}, \mathrm{CD}_{3} \mathrm{OD}\right): \delta=14.4,14.6,23.58$, 23.64, 27.6, 30.0, 32.41, 32.43, 33.2 (d, J 6 Hz), 34.6 (d, J $27 \mathrm{~Hz}$ ), 104.4 (d, J $24 \mathrm{~Hz}$ ), 114.1, 128.8, 132.4, 134.0, 135.0, 135.9, 170.1, 171.0 (d, J $279 \mathrm{~Hz}$ ). ${ }^{19} \mathrm{~F} \mathrm{NMR} \mathrm{(376} \mathrm{MHz,} \mathrm{CD} \mathrm{CD}$ ): $\delta=-76.8$. HRMS (FAB, double focusing): $\mathrm{m} / z[\mathrm{MH}]^{+}$calcd for $\mathrm{C}_{19} \mathrm{H}_{27} \mathrm{FIO}_{2}$ : 433.1034; found: 433.1040 .

\section{References}

1. The Merck Index, The Merck Index: An Encyclopedia of Chemicals, Drugs, and Biologicals, Merck \& Co.

2. Allmendinger, T.; Furet, P.; Hungerbühler, E. Tetrahedron Lett. 1990, 31, 7297.

https://doi.org/10.1016/S0040-4039(00)88548-2

3. Allmendinger, T.; Felder, E.; Hungerbühler, E. Tetrahedron Lett. 1990, 31, 73301.

https://doi.org/10.1016/S0040-4039(00)88548-2

4. Welch, J. T.; Allmendinger, T. in Peptidomimetics Protocols; Kazmierski, W. M., Ed.; Humana Press: Tolowa, NJ, 1999; p. 357.

5. Stang, P. J.; Zhdankin, V. V. Chem. Rev. 1996, 96, 1123. https://doi.org/10.1021/cr940424+

6. Zhdankin, V. V.; Stang, P. J. Chem. Rev. 2002, 102, 2523. https://doi.org/10.1021/cr010003+

7. Zhdankin, V. V.; Stang, P. J. Chem. Rev. 2008, 108, 5299. https://doi.org/10.1021/cr800332c

8. Yoshimura, A.; Zhdankin, V. V. Chem. Rev. 2016, 116, 3328. https://doi.org/10.1021/acs.chemrev.5b00547

9. Zhdankin, V. V. Hypervalent lodine Chemistry: Preparation, Structure and Synthetic Application of Polyvalent lodine Compounds; John Wiley \& Sons: Chichester, 2014.

https://doi.org/10.1002/9781118341155

10. Okuyama, T.; Takino, T.; Sueda, T.; Ochiai, M. J. Am. Chem. Soc. 1995, 117, 3360.

https://doi.org/10.1021/ja00117a006 
11. Hara, S.; Yamamoto, K.; Yoshida, M.; Fukuhara, T.; Yoneda, N. Tetrahedron Lett. 1999, 40, 7815. https://doi.org/10.1016/S0040-4039(99)01626-3

12. Yoshida, M.; Hara, S.; Fukuhara, T.; Yoneda, N. Tetrahedron Lett. 2000, 41, 3887. https://doi.org/10.1016/S0040-4039(00)00494-9

13. Yoshida, M.; Nagahara, D.; Fukuhara, T.; Yoneda, N.; Hara, S. J. Chem. Soc. Perkin Trans. $12001,2283$. https://doi.org/10.1039/b101836l

14. Yoshida, M.; Yoshikawa, S.; Fukuhara, T.; Yoneda, N.; Hara, S. Tetrahedron 2001, 57, 7143. https://doi.org/10.1016/S0040-4020(01)00683-4

15. Yoshida, M.; Hara, S. Org. Lett. 2003, 5, 573. https://doi.org/10.1021/ol027512y

16. Yoshida, M.; Kawakami, K.; Hara, S. Synthesis 2004, 2821. https://doi.org/10.1055/s-2004-834857

17. Yoshida, M.; Komata, A.; Hara, S. Tetrahedron 2006, 62, 8636. https://doi.org/10.1016/j.tet.2006.05.085

18. Hara, S.; Yoshida, M.; Fukuhara, T.; Yoneda, N. Chem. Commun. 1998, 965. https://doi.org/10.1055/s-1998-1714

19. Kitamura, T.; Mizuno, S.; Muta, K.; Oyamada, J. J. Org. Chem. 2018, 83, 2773. https://doi.org/10.1021/acs.joc.7b03223

20. Brand, J. P.; González, D. F.; Nicolai, S.; Waser, J. Chem. Commun. 2011, 47, 102. https://doi.org/10.1039/COCC02265A

21. Kitamura, T.; Kuriki, S.; Morshed, M.H.; Hori, Y. Org. Lett. 2011, 13, 2392. https://doi.org/10.1021/ol200632d

22. Kitamura, T.; Kuriki, S.; Muta, K.; Morshed, M.H.; Muta, K. Synthesis 2013, 45, 3125. https://doi.org/10.1055/s-0033-1339672

23. Kitamura, T.; Muta, K.; Kuriki, S. Tetrahedron Lett. 2013, 54, 6118. https://doi.org/10.1016/i.tetlet.2013.08.129

24. Kitamura, T.; Muta, K.; Muta, K. J. Org. Chem. 2014, 79, 5842. https://doi.org/10.1021/jo500691b

25. Kitamura, T.; Muta, K.; Oyamada, J. Synthesis 2015, 47, 3241. https://doi.org/10.1055/s-0034-1378747

26. Kitamura, T.; Muta, K.; Oyamada, J. J. Org. Chem. 2015, 80, 10431. https://doi.org/10.1021/acs.joc.5b01929

27. Kitamura, T.; Miyake, A.; Muta, K.; Oyamada, J. J. Org. Chem. 2017, 82, 11721. https://doi.org/10.1021/acs.joc.7b01266

28. Kitamura, T.; Yoshida, K.; Mizuno, S.; Miyake, A.; Oyamada, J. J. Org. Chem. 2018, 83, 14853. https://doi.org/10.1021/acs.joc.8b02473

29. Kraszkiewicz, L.; Skulski, L. Arkivoc 2003, vi, 120. https://doi.org/10.3998/ark.5550190.0004.312

30. Nicolai, S.; Piemontesi, C.; Waser, J. Angew. Chem. Int. Ed. 2011, 50, 4680. https://doi.org/10.1002/anie.201100718 